\title{
Real acts, imagined landscapes: Reflections on the discourses of land reform in South Africa after 1994
}

\author{
Andries du toit
}

\begin{abstract}
This paper discusses the discourses by which land reform policies in South Africa have been justified and criticized. Critical thought is needed about the underlying assumptions and frameworks informing policy and critique. While key aspects of populist, 'Left' and liberal ideologies helped mobilize support for land reform after 1994, they framed questions of equitable transformation and justice in ways that obscured the terrain of struggle rather than revealing it. The broad consensus on the legitimacy of land reform in the initial decade after 1994 was underpinned by narratives about redress and reconciliation that privileged reparative justice above distributive equity. It tended to obscure the complex trade-offs and impacts involved in implementation. Coherent policy-making was further undermined by simplistic oppositions between 'market' and 'rights-based' approaches that often led to ill-targeted policies. Land and agrarian reform needs to be liberated from this symbolic burden. It should be informed by an understanding of the nature of inequality in South Africa and the contribution that agrarian change can make to reducing it.
\end{abstract}

\section{Time to think}

Why do we want land and agrarian reform in South Africa? Why should its policies be supported? Much can be said about its stated purposes and goals, but why do these goals matter - and to whom? Rather than evaluate land policies in terms of their own objectives, this paper sets them in context and explores their role in the larger moral and ideological economy of post-Apartheid politics. There are divergent understandings of what land and agrarian reform is about, or why it matters. Land and agrarian reform is contested, available to be annexed or appropriated by a range of different political and ideological projects. Moreover, 'land reform' is hardly ever only about land. 'Land' matters not simply as a resource or material reality, but also as an empty signifier (Laclau 1990): a 'field of meaning' available for appropriation by a wide range of different political projects; a powerful, material metaphor for deeply conflictual political processes extending well beyond the matters directly addressed in land reform policy.

Andries du Toit, Institute for Poverty, Land and Agrarian Studies, University of the Western Cape, Private Bag X17, Bellville 7535, South Africa. E-mail: adutoit@plaas.org.za

The thoughts set out here arise from many years and hundreds of conversations with friends and colleagues. Particular acknowledgements are due to Henry Bernstein, Deena Bosch, Colleen Crawford Cousins, Lungisile Ntsebeza, Cherryl Walker and Gavin Williams. My thanks are also due to the anonymous reviewers of this article. But this piece is particularly dedicated to the memories of Kobus Pienaar and Johann Hamman, fighters for equitable rural change and social justice, both of whom played a crucial role in the early years of this debate, but who are not around anymore to continue it. 
Land reform is therefore in part also a metaphorical act, and relates to struggles and antagonisms that extend well beyond its literal and material consequences. These issues cannot be ignored. We need to think more critically about how land and agrarian reform is imagined and evaluated. Without such thinking, questions of equitable transformation and justice are too easily framed in ways that obscure the terrain of struggle rather than revealing it, and which make complex policy questions harder, rather than easier, to resolve.

\section{A fragile consensus}

One of the more interesting aspects of the land reform agenda of the early 1990 s is that it existed at all. In the early years of the transition, the South African debate about land and agrarian policy seemed irreconcilably divided (the ANC for mass collectivization; an NGO Left built around the struggles of isolated rural communities; an urban-based union movement informed by an adversarial, industrial model of labour relations; truculent representatives of 'organized' - i.e. white - agriculture promising to let loose the dogs of war if their way of life was interfered with; and business opinion - also white - seeing white farming as a liability, but deeply worried about nationalization and property rights). In a short while this gave way to a broad consensus around the Department of Land Affairs' White Paper on land reform (DLA 1997). Usually, accounts of this shift focus on the compromise on the property clause (e.g. Ntsebeza 2007), but this does not answer the question of what enabled this compromise to be accepted so widely. An important role was played by a series of policy interventions (by the World Bank, but also by South African agricultural economists inside the DBSA and policy- makers inside the ANC) that allowed the development of an agenda that appeared to reconcile the aims of national reconciliation, deracialization, global economic integration and jobs for the poor (Williams 1996; Hall 2010). This was made possible by the way in which these very different projects were framed as elements of a seamless narrative of enlightened humanist modernization.

This programme commanded assent across a wide spectrum of political opinion. But this support drew on a number of different legitimizing frameworks, each of which presupposed a very different political project. One discourse was primarily concerned with notions of national food security, sustainability and economic efficiency. Land reform, from this point of view, required the abolition of the institutional environment that had protected inefficient farmers from market pressures and that had created an oppressive racial order in the countryside. The aim was to create an efficient, globally integrated and deracialized commercial agricultural sector.

A second framework situated land reform within the problematic of national reconciliation, restorative justice and reparation. Support for land reform was premised on the need to deal with the politically charged legacy of land theft and dispossession. This discourse had two very different inflections: on the one hand, there was a populist, African nationalist project that emphasized the injustice of colonial land theft 
and problematized the legitimacy of the post-Apartheid racial order as such. Closely related to it but quite distinct, was an essentially liberal discourse focusing on restitution, reconciliation and redress within a post-1910 framework.

A third framework understood injustice as pivoting crucially on the violation of human rights. From this point of view, land and agrarian reform needed to create a legal framework that could protect and empower the marginalized and vulnerable. A fourth stream saw land reform as serving the aims of equitable economic growth and agrarian transformation, and saw land reform as 'kickstart[ing] rural development' (ANC 1994).

The ability to link these four discursive frameworks was at one and the same time the programme's greatest strength and its greatest weakness. The narrative crafted by the RDP and the White Paper presented land reform as of a 'win-win' process that would deliver stability, reconciliation, justice and economic growth. But its very success in creating a compelling metanarrative made it all the more difficult to name, and engage with, the contradictions and tensions that emerged when trying to implement this vision.

\section{Dreams of reparation}

One consequence was that the implementation of land reform became entangled with the psychological and political aftermath of Apartheid's history, and the challenge it posed for the formation of a coherent national identity. An important role was played by the apparent fragility of the consensus upon which political stability depended, and the enormous risks (real or imagined) associated with the dread possibility of a return to de facto civil war. But these dynamics also contributed to the highly charged nature of the terrain of reconstruction itself. Anger at the injustices of the past; fear of retribution; sorrow, fear and guilt about injustices caused; confused desires for redemption and vindication - all these were (and still are!) richly present for all participants. This means that the politics of South African identity formation are what Freudians would call deeply cathected: every event or act is pregnant with meanings infused by histories well beyond the intentions of the actors; every fact (however nuanced and complex reality might be) is available for construction as evidence for powerful and often reductive narratives of betrayal, retribution, bad faith, triumph, failure and so on.

Into this superheated crucible fell the policies and implementation of rural development and land reform. Cherryl Walker has described the burdens imposed by this reparative project on the implementation of land restitution (Walker 2005). One of the striking aspects of restitution policy has been the disjuncture between the wide and unreflective public support for the idea of restitution and the messy, conflictual and unsatisfactory nature of implementation. On the Left, this is commonly seen simply as the result of promises betrayed and the failure of 'political will'. Others blame bureaucratic incompetence and inefficiency. What these explanations fail to take into account are the difficulties that arise when the implementation of real-world policy is entangled with an essentially symbolic drama: one in which the injustices suffered by specific claimants 
come to stand for the violence of Apartheid itself; in which claimants come to represent Apartheid's victims as such; and in which the redress of particular wrongs serves as metaphorical healing for 'the nation' as a whole. Compelling as these associations might be, they do not offer a helpful framework for the resolution of the significant real-world complexities of implementation. Rather than a process in which victims could be (actually and symbolically) recompensed, restitution has become a policy deluged by jostling victims with conflicting and overlapping claims - and this in a rights-based and judicial framework in which anyone with access to a lawyer can hold the process hostage.

The converse is also true. The problem is not only that land reform implementation can be derailed by symbolic politics. In addition, nation-building is not served by making something as important as 'national reconciliation' and the legitimacy of the postApartheid order depen- dent on something as tricky as land reform.The sustainability of the post-Apartheid order does require dealing with the political legacies of the past. But these legacies should be addressed in more effective and constructive ways, and need to go well beyond the specificities of local histories of land loss.

Quite distinct from the restitution project's concern with reconciliation and nationbuilding are more populist approaches that expect land reform to address the history of colonial land theft before 1910. As is evident from Mugabe's famous description of the need for land reform as 'the last colonial question' (Mugabe 2000), such demands problematize the legitimacy of the post-colonial political order as such. Given the lack of equitable social change and the persistence of deep racial inequalities 17 years after the transition, their appeal is understandable. But such demands have dangerous consequences for progressive politics - and not only because of the potential destructiveness of a Zimbabwe-style 'fast track land reform' for South Africa. As Walker has pointed out, these discourses give pride of place to Apartheid-era and essentialist constructions of identity, and often marginalize gender (Walker 2005). In addition, they are often premised on idealized notions of a pre-colonial past. The tendency to link land and identity so closely and ahistorically creates huge problems in the context of the high degrees of migrancy, mobility and ongoing displacement to be found in present-day Southern Africa. In addition, essentialist Africanist discourses about colonial land theft potentially provide ideological cover for processes of elite enrichment that have little to do with equitable change.

\section{Rights and violations}

The enactment of reparative fantasies is not the only way in which concerns with historical injustices animate land and agrarian reform policy. It is also important to consider a related but distinct project - one that is focused on the protection and realization of human rights. Here, I want to focus on the difficulties faced by rights-based approaches in engaging effectively with equitable transformation on South Africa's commercial farmlands. These difficulties relate in particular to the way in which rightsbased approaches often involve a tendency to frame issues of social justice as pivoting essentially on the defence of people against the violation of their rights by other actors (see, e.g., HRW 2011). Advocacy campaigns on behalf of farm workers or other 
marginalized rural people all too often portray poor and marginal people simply as powerless victims who need to be rescued or defended from the depredations of powerful persecutors. It is easy to see why this happens - particularly when campaigners need to appeal to distant, apolitical and uninformed audiences in the global North. But powerful as such narratives are, they can lead to a dangerous narrowing of the scope of concern. Activists are not well served by a legal framework that allows them only to become involved when there has been a violation. Not only do such approaches involve unrealistic expectations about the extent and reach of the regulatory power of a capacity-strapped state. In addition, they all too often involve an exclusive concern with the apparent exceptionalism of particular violations, while failing to problematize the exploitative social relations and impoverishing practices that constitute the normal operations of capitalist economies.

Perhaps the most significant example is the promulgation and implementation of the Extension of Security of Tenure Act (ESTA) of 1997, which sought to address farm worker vulnerability by creating a regulatory framework for evictions and by providing for the establishment of tenure rights at retirement age for long-term farm dwellers. It may indeed be that this strong emphasis on land rights was appropriate in parts of the country (e.g. in Limpopo) where the key interests of farm workers themselves were indeed bound up with long-existent and economically vital relationships to contested land (Cousins and Hall 2011). But in labour-absorptive Western Cape horticulture, where farm workers' livelihoods were primarily dependent on employment, and where a high degree of mobility was an essential part of the survival and coping strategies of a transient farm dweller population (Waldman 1993), the policy did little to shift power relations in farm workers' favour, and arguably did much to worsen them. Research is divided on the extent to which ESTA contributed to the uneven but significant trend towards the downsizing, casualization and externalization of farm labour.

Clearly agro-food deregulation, supermarket power, price pressure and the tightening of labour law also played a key role. But it is hard to deny that it exacerbated those trends (Du Toit and Ally 2004; Ewert and Du Toit 2005). With the stroke of a pen, the promulgation of ESTA turned Western Cape farmers' investments in farm worker housing into liabilities: while, in the 1980s, modernizing employers had seen the improvement of housing as essential to retaining skilled workers, housing was now seen as a foothold for the establishment of unwanted tenure rights. It also killed off any chance, slender though it may have been, of a 'corporatist deal' in which progressive elements of commercial agriculture, the state and the union movement could agree on ways in which farm employment could be protected under conditions of globalization.

The issue is not whether rights in general are good things (obviously the entrenchment and defence of rights can be vital), but the question is which rights, how and where. The answers to those questions need to be based on an understanding of the nature of capitalist exploitation, historical process and local social relations of power. In the absence of such an understanding, purely rights-based approaches have little critical traction, and can all too easily be marginalized or appropriated by a liberal politics.That, 
at any rate, is what happened on the farmlands of the Western Cape. The tendency of rural CBOs and NGOs to focus on the excesses of an increasingly beleaguered and marginalized white family farming class have led them to ignore, and sometimes even to collude with, the large-scale consolidation of corporate and agribusiness power.

\section{Placing distributive justice at the centre}

What then, are the options for an agrarian politics concerned with social equity in South Africa? A concern with reparative justice all too easily sidelines a focus on presentday distributive justice, and a narrow focus on rights (including land rights) risks ignoring or legitimizing the social processes and relations of capitalist exploitation. What would it look like to put distribu- tive justice and a concern with social inequality at the centre of agrarian policy? This is a complex issue, but it is possible to list some basic strictures, warnings and guidelines.

Understand and accept the reality of urbanization. To begin with, any agrarian policy needs to accept the 'extreme and exceptional' nature of the South African 'land question' as articulated by Henry Bernstein (1996). Agrarian policy cannot be about 'turning back the clock'. It has to be about equitable social transformation in the interests of South Africa's poor as they exist at this moment in history - including the urban poor. Land and agrarian reform is not an exclusively 'rural' matter: it is about food security, economic justice and livelihoods both in town and in the countryside.This means that agricultural land should be seen as a valuable national resource - and that land reform policy should consider the food needs of the urban poor.

From this, it follows that the challenges arising out of 'the land question' cannot be dealt with in terms of land policy alone. The marginalization and structural exclusion created by land theft (and by capitalist adverse incorporation) needs to be dealt with - but the response needs to take the form of a coherent policy for pro-poor growth that informs economic policy more generally. Similarly, the potent political charge created by the memories and transmitted histories of Apartheid injustices need to be dealt with - but it is only in a small minority of cases that they can be dealt with through the vehicle of land reform.

This does not mean that there is not a land question. We should accept the reality of poor people's land demands: but this is not a demand for a return to an agrarian past. It is a demand for tenure security and residential land that will allow for security, survival and 'accumulation from below' in the harsh and unforgiving context of the present-day South African economy. The key problem relates essentially to design of equitable human settlements, local government, land use and spatial planning. One question is how land reform can be used more assertively to reconfigure Apartheid's spatial legacy in rural areas. Another challenge is developing a sense of how tenure security and land-based activities form part of a mix of economic activities in peri-urban areas and denser rural settlements (Aliber et al. 2011). We should, by the way, forgo the stirring and meaningless talk about 'vibrant rural communities' that characterizes develop- ment speak on this issue (e.g. DRDLR 2009). Such language merely encourages a flight into fantasy. We should focus instead on the reality of what's there - marginalized and 
hybrid livelihoods supported by remittances, social grants and informal self-employment - and figure out how these can be protected, sustained and encouraged to grow.

We should recognize that we still lack convincing models of commercial agriculture that are economically equitable and environmentally sustainable. Here, we are in a double bind. Large-scale commercial agriculture is unlikely to contribute to meaningful levels of employment, is unsustainably reliant on fossil fuels and agrochemicals, and without expensive racial transformation it will remain a political embarrassment. The potential of small-scale agriculture to deal with these difficulties is a matter of intense scholarly debate (see, e.g.,Wiggins 2009). Although small-scale agriculture may be more efficient in some respects, and though it is probably more employment intensive, small-scale farmers are poorly positioned to compete in centralized, buyer-driven value chains, are not necessarily more committed to sustainable practices, and are unlikely to be able to meet the urban poor's demand for cheap food (Mather 2005). More seriously, even if a small-farmer sector could in theory meet all these requirements, there is the small matter of getting there. Outcomes are path dependent, and transformation will be costly. There is a need to go beyond general and ideological battles around the virtues of small- versus large-scale farming; and to explore whether there are viable and workable models for change.

A focus on land and agrarian reform that looks only at landownership and at primary production is misdirected, and will ignore the ways in which agribusiness and large corporations are trans- forming the agro-food sector in their own interests. A progressive agrarian policy will therefore need to focus on the contestation of power relations in the food system as a whole. While land reform implementation has gone adrift, and while rural NGOs have focused on the outrage of human rights violations by a dwindling population of commercial farmers, the stable door is open and the horse has bolted: commercial restructuring of agriculture here and abroad is driving processes of jobless de-agrarianization for huge surplus populations who have been pushed off the land, but who are no being reabsorbed into non-farm employment ( $\mathrm{Li}$ 2007). One challenge is developing approaches to reining in corporate power, and at the very least ensuring that value chain governance happens in more pro-poor ways. Another is finding ways of supporting the development of local food economies not entirely dominated by corporates, and in which small farmers and local vendors can participate.

What emerges, then, is a politics of agrarian reform that perhaps seems much more modest. The argument of this paper involves questioning the heroic role often thrust upon 'land reform' in popular imagination on the Left. Far from seeing land reform as a central, self-contained project of massive redistribution, it is better imagined as a component of a much more encom- passing but also more constrained process of political and socio-economic change in South African society as a whole.

Does this amount legitimizing the 'status quo' in the South African countryside? I do not think so. A radical project of critique and fostering equitable social change in South Africa is possible. But such a project has to start with a recognition of the terrain as it exists at this time, not as we would wish it to be; with an accurate assessment of where the critical points of contestation really are - and with critical awareness of 
the often unexamined underlying assumptions, desires and fantasies that animate and inform discussion about what is, and what should be, in our agro-food system. 


\section{References}

ANC (African National Congress), 1994. The Reconstruction and Development Programme: A Policy Framework. Cape Town: African National Congress.

Aliber, M., T. Maluleke, T. Manenzhe, G. Paradza and B. Cousins, 2011. Livelihoods after Land Reform: Trajectories of Change in Limpopo Province, South Africa. PLAAS Research Report no. 43. Bellville:Institute for Poverty,Land and Agrarian Studies.

Bernstein, H., 1996. 'South Africa's Agrarian Question: Extreme and Exceptional?' Journal of Peasant Studies, 23 (2/3): 2-41.

Cousins, B. and R. Hall, 2011. 'Rights without Illusions: The Potential and Limits of Rights-Based Approaches to Securing Land Tenure in Rural South Africa'. PLAAS Working Paper 18. Bellville: Institute for Poverty, Land and Agrarian Studies.

DLA, 1997. White Paper on South African Land Policy. Pretoria: Department of Land Affairs.

DRDLR, 2009. The Comprehensive Rural Development Programme Framework. Pretoria: Ministry of Rural Development and Land Reform.

Du Toit,A. and F.Ally, 2004. The Externalization and Casualisation of Farm labour in the Western Cape. PLAAS Research Report No.16. Bellville: PLAAS and CRLS.

Ewert, J. and A. Du Toit, 2005.'A Deepening Divide in the Countryside: Restructuring and Rural Livelihoods in the South African Wine Industry'.Journal of Southern African Studies,31(2):31532.

Hall, R., 2010. 'The Politics of Land Reform in Post-Apartheid South Africa, 1990 to 2004: A Shifting Terrain of Power,Actors and Discourses'.Thesis submitted in fulfilment of the requirements for the Degree of Doctor of Philosophy in Politics and International Relations (unpublished typescript).

HRW, 2011. Ripe with Abuse: Human Rights Conditions in South Africa's Fruit and Wine Industries. New York: Human Rights Watch.

Laclau, E., 1990. New Reflections on the Revolution of Our Time. London: Verso.

Li,T.,2007. The Will to Improve: Governmentality, Development, and the Practice of Politics. Durham, NC: Duke University Press.

Mather, C, 2005. 'The Growth Challenges of Small and Medium Enterprises (SMEs) in South Africa's Food Processing Complex'. Development Southern Africa, 22 (5): 607-22.

Mugabe, R.G., 2000. 'Land: Zimbabwe's Last Colonial Question'. Transcription of televised address by Robert Mugabe, the President of Zimbabwe, to mark the twentieth anniversary of the country's independence. The Independent, 20 April, http://www.independent.co.uk/opinion/commentators/land-zimbabwes-last-colonial- question717710.html (accessed 30 July 2012).

Ntsebeza, L., 2007.'The Property Clause ...'. In The Land Question in South Africa:The Challenge of Transformation and Redistribution, eds L. Ntsebeza and R. Hall. Pretoria: Human Sciences Research Council Press.

Waldman, L., 1993.'HereYouWill Remain:Adolescent Experience on Farms in theWestern Cape'. Unpublished MA dissertation, University of Cape Town.

Walker, C., 2005.'The Limits to Land Reform: Rethinking “the Land Question”'. Journal of Southern African Studies, 31 (4): 805-24.

Wiggins, S., 2009.'Can the Smallholder Model Deliver Poverty Reduction and Food Security for a Rapidly Growing Population in Africa?’ FAC Working Paper No. 08. Brighton: Future Agricultures Consortium. Williams, G., 1996. 'Setting the Agenda: A Critique of the World Bank's Rural Restructuring Programme for South Africa'.Journal of Southern African Studies, 22 (1):139-66. 